\title{
Effects of prepartum zinc-methionine supplementation on feed digestibility, rumen fermentation patterns, immunity status, and passive transfer of immunity in dairy cows
}

\author{
Fengting Chen, ${ }^{1 *}$ Yan Li, ${ }^{2 *}$ Yizhao Shen, ${ }^{1 *}$ † Yanfei Guo, ${ }^{1}$ Xiaojing Zhao, ${ }^{3}$ Qiufeng Li, ${ }^{1,4}$ Yufeng Cao, ${ }^{1,4}$ \\ Xiujiang Zhang, ${ }^{5}$ Yunqi $\mathrm{Li}^{1}{ }^{1}$ Zhonghua Wang ${ }^{6}$ Yanxia Gao, ${ }^{1,4} \dagger$ and Jianguo $\mathrm{Li}^{1,4} \dagger$ \\ ${ }^{1}$ College of Animal Science and Technology, Hebei Agricultural University, Baoding 071001, Hebei, P.R. China \\ ${ }^{2}$ College of Veterinary Medicine, Hebei Agricultural University, Baoding 071001, Hebei, P.R. China \\ ${ }^{3}$ Baoding Vocational and Technical College, Baoding 071000, Hebei, P.R. China \\ ${ }^{4}$ Hebei Cattle and Sheep Embryo Engineering Technology Research Center, Baoding 071001, Hebei, P.R. China \\ ${ }^{5}$ Baoding Husbandry Work Station, Baoding 071001, Hebei, P.R. China \\ ${ }^{6}$ Shandong Agricultural University, Taian 271000, Shandong, P.R. China
}

\begin{abstract}
The aim of this study was to determine the effects of prepartum supplementation of zinc-methionine ( $\mathrm{Zn}$ Met) on feed digestibility, rumen fermentation patterns, and immunity status in dams and passive immunity transfer in their calves. A randomized complete design was used in this study. Forty multiparous Holstein dairy cows in late pregnancy $(60 \mathrm{~d}$ before the expected calving date) were blocked by parity $(2.1 \pm 0.3)$, body weight $(651 \pm 52 \mathrm{~kg})$, and expected calving date, and randomly assigned to 1 of 4 treatments. Cows were supplemented with Zn as Zn-Met at 0, 20, 40, or $60 \mathrm{mg} / \mathrm{kg}$ of dry matter (DM) from $60 \mathrm{~d}$ before expected calving date to the calving day. Though the nutrient digestibility was not affected by Zn supplementation, DM intake, $\mathrm{Zn}$ digestibility, and $\mathrm{Zn}$ deposition increased linearly with increasing Zn-Met supplementation. Ruminal pH and molar proportion of individual volatile fatty acids were similar, whereas a linear decrease and increase were observed in ruminal ammonia and microbial crude protein concentration, respectively, with increasing Zn-Met supplementation. Maternal serum concentration of alkaline phosphatase, carboxypeptidase, $\mathrm{Cu}$ and $\mathrm{Zn}$ superoxide dismutase, and total antioxidant capacity were greater in cows supplemented with $>40$ $\mathrm{mg}$ of $\mathrm{Zn} / \mathrm{kg}$ of DM compared with the control group. With increasing Zn-Met supplementation, maternal blood concentration of IL-1 decreased linearly, whereas IL-2 and IL-6 increased linearly, and no differences
\end{abstract}

Received November 30, 2019

Accepted May 15, 2020.

*These authors contributed equally to this work.

†Corresponding authors: yanxia.gao@hebau.edu.cn and shenyizhao@ hebau.edu.cn were observed in IL-4. Concentration of nonesterified fatty acids and $\beta$-hydroxybutyric acids in maternal blood was similar between treatments. No difference was observed in colostrum composition with increasing Zn-Met supplementation. Concentration of $\mathrm{Zn}$ and immunoglobulins (including $\operatorname{IgA}, \operatorname{IgG}$, and $\operatorname{IgM}$ ) in maternal blood did not differ among treatments. However, Zn concentration in colostrum and blood of calves increased linearly. The concentration of IgA and IgM in colostrum increased linearly with increasing Zn-Met supplementation, whereas no differences in immunoglobulins were observed in calf blood. In conclusion, Zn supplementation as Zn-Met at 40 of $\mathrm{mg} / \mathrm{kg}$ of DM may improve antioxidant activity of dam and potentially increase passive immunity transfer in calves.

Key words: zinc metabolism, zinc-dependent enzyme, antioxidant capacity, colostrum composition, immunoglobulin

\section{INTRODUCTION}

Zinc is an essential micronutrient in animals, as it is a cofactor of numerous enzymes. Zinc further plays an important role in protein synthesis, gene regulation, and immune function (Weiss, 2017). In dairy cows, Zn supplementation may enhance milk production and blood concentration of cytokines and immunoglobulins and decrease the SCC in lactating cows (Pfeiffer et al., 1977; Stefanidou et al., 2006; Cope et al., 2009). The Zn can also improve the health status of dairy calves (Wright and Spears, 2004). However, research on the effects of Zn supplementation in prepartum cows and subsequent postpartum performance is scarce. Because $\mathrm{Zn}$ is beneficial to the immune response (Stefanidou et al., 2006), we hypothesized that Zn supplementation may have potential benefits for passive immunity transfer through colostrum. 
Dietary $\mathrm{Zn}$ can be fed in inorganic or organic form. Usually, organic Zn has greater utilization efficiency (Wedekind et al., 1992; Garg et al., 2008). One plausible reason for this observation might be that more of the inorganic $\mathrm{Zn}$ than organic $\mathrm{Zn}$ readily reacts with other chemicals in the digestive tract, creating indigestible complexes (Uchida et al., 2001). Moreover, Zn metabolism may be different in organic form compared with inorganic form as reported by Wedekind et al. (1992). Zinc-methionine (Zn-Met) is an organic $\mathrm{Zn}$ source that is widely used in animals. Wedekind et al. (1992) found that both DMI and weight gain were greater in chicks supplemented with Zn-Met than $\mathrm{ZnSO}_{4}$ or $\mathrm{ZnO}$. Garg et al. (2008) reported greater fiber digestibility, Zn retention, DMI, ADG, and feed efficiency in lambs supplemented with Zn-Met compared with $\mathrm{ZnSO}_{4}$. Moreover, cows supplemented with Zn-Met might experience reduced SCC (Kellogg et al., 2004; Sobhanirad et al., 2010). All of the previous studies demonstrated that Zn-Met should be a bioavailable Zn source in dairy cows.

However, the optimum dose of Zn-Met has not been well defined. Cope et al. (2009) reported an increase in milk yield and decrease in SCC in cows supplemented with organic Zn at 65 versus $40 \mathrm{mg} / \mathrm{kg}$ of DM. Kel$\operatorname{logg}$ et al. (2003) reported improved production and reproduction performance in cows supplemented at 360 $\mathrm{mg}$ of $\mathrm{Zn} / \mathrm{d}$, which was approximately equal to $20 \mathrm{mg}$ of $\mathrm{Zn} / \mathrm{kg}$ of DM. Hence, we set up an experiment to evaluate the effect of organic $\mathrm{Zn}$ dosage in the prepartum period on (1) DMI, nutrient digestibility in the total digestive tract, rumen fermentation characteristics, and Zn metabolism and (2) passive immunity transfer from dam to calves.

\section{MATERIALS AND METHODS}

This study was conducted between October 2017 and January 2018 at Jiulonghe dairy farm in Baoding, P. R. China. The experimental protocol (YXG 1711) was approved by the Institutional Animal Care and Use Committee of Hebei Agricultural University.

\section{Animals, Diets, and Experimental Design}

Forty multiparous Holstein dairy cows in late pregnancy ( $60 \mathrm{~d}$ before expected calving date) were blocked by parity ( $2.1 \pm 0.3$; range from $2-3)$, BW $(651 \pm 52$ $\mathrm{kg})$, previous 305 -d milk yield $(8,129 \pm 367 \mathrm{~kg})$, DMI, and expected calving date and randomly assigned to 4 treatments. The Zn-Met supplemental period lasted from $60 \mathrm{~d}$ before expected calving date to the day of calving. The actual supplemental period was $57.3 \pm$
Table 1. Ingredients and chemical composition of the experimental diets

\begin{tabular}{lcc}
\hline & \multicolumn{2}{c}{ Diet } \\
\cline { 2 - 3 } Item & Dry period & Prepartum \\
\hline Ingredient, \% of DM & 24.8 & 25.8 \\
Oat hay & 15.6 & 15.6 \\
Corn silage & 28.8 & 28.8 \\
Chinese wildrye hay & 3.06 & 4.06 \\
Corn DDGS & 3.56 & 2.56 \\
Wheat bran & 5.00 & 3.50 \\
Cracked corn & 6.38 & 6.58 \\
Beet pellet & 4.48 & 5.78 \\
Soybean meal & 3.30 & 2.30 \\
Steam-flaked corn & 3.52 & 3.52 \\
Cottonseed meal & 1.57 & 1.57 \\
Premix & & \\
Chemical composition, DM basis & 1.34 & 1.34 \\
NE ${ }^{3}{ }^{1}$ Mcal/kg & 12.1 & 13.4 \\
CP, \% & 3.16 & 3.92 \\
Ether extract, \% & 46.0 & 46.4 \\
NDF, \% & 25.9 & 26.3 \\
ADF, \% & 0.45 & 0.55 \\
Ca, \% & 0.22 & 0.27 \\
P, \% & 21.5 \\
Zn, mg/kg & & 21.3 \\
\hline
\end{tabular}

${ }^{1}$ DDGS $=$ dried distillers grains with solubles.

${ }^{2}$ Premix contained (per $\mathrm{kg}$ of DM): 800,000 IU of vitamin A, 180,000 IU of vitamin $D_{3}, 7,000 \mathrm{mg}$ of vitamin $\mathrm{E}, 45 \mathrm{mg}$ of biotin, $300 \mathrm{mg}$ of $\beta$-carotene, $600 \mathrm{mg}$ of $\mathrm{Cu}, 1,000 \mathrm{mg}$ of $\mathrm{Fe}, 1,800 \mathrm{mg}$ of $\mathrm{Mn}, 20 \mathrm{mg}$ of $\mathrm{Co}, 30 \mathrm{mg}$ of Se, and $39 \mathrm{mg}$ of $\mathrm{I}$.

${ }^{3}$ Data were calculated according to NRC models (NRC, 2001).

$4.55 \mathrm{~d}$ (range from 53-68 d) according to the actual calving date. Dairy cows were fed a TMR thrice daily at 0600,1300 , and $1900 \mathrm{~h}$. The diet was formulated according to NRC (2001), and the ingredients and nutritional composition are shown in Table 1 . Cows were changed to the prepartum diet from the dry period diet at $21 \mathrm{~d}$ before expected calving date. Cows were housed individually in tiestalls with ad libitum access to TMR (ensuring at least $5 \%$ refusals) and fresh water. The cows had outdoor exercise from 2200 to $0600 \mathrm{~h}$ daily prepartum. Only fresh water was accessible during the outdoor exercise periods. Feed refusals were cleaned up 3 times per day before each feeding.

Four treatments $(\mathrm{n}=10$ /treatment $)$ were as follows: control (no Zn-Met supplemented in diet) and the control diet supplemented with Zn at 20,40, or $60 \mathrm{mg} /$ $\mathrm{kg}$ of DM as Zinpro Zn-Met complex (Zinpro Corp., Eden Prairie, MN). The Zn-Met was mixed with $72 \mathrm{~g}$ of ground corn and $18 \mathrm{~g}$ of molasses, split into 3 portions, and top dressed thrice daily immediately after feed offered. Cows from the control group received $72 \mathrm{~g}$ of ground corn and $18 \mathrm{~g}$ of molasses only by top dressing. The top dress for every cow was prepared weekly according to the DMI. Briefly, Zn-Met was weighed into a plastic container by cow, ground corn and molasses 
for 40 cows for $7 \mathrm{~d}$ were mixed using a Hobart mixer (model H662, Hobart Corp., Troy, OH), and $90 \mathrm{~g}$ of mixture was added to each container.

\section{Sampling and Data Collection}

Feed offered and refusals of each cow were recorded daily during the experimental period (from $60 \mathrm{~d}$ before expected calving date to calving). Feed ingredients and TMR were collected weekly; feed refusals were sampled every last $3 \mathrm{~d}$ of the week, pooled by treatments, and oven-dried at $55^{\circ} \mathrm{C}$ for $48 \mathrm{~h}$ for DM content determination, and then ground to pass through a $1-\mathrm{mm}$ screen (standard model 4 Wiley mill; Arthur H. Thomas, Philadelphia, PA) for chemical analyses. The DMI was calculated weekly as the difference between DM offered and DM refusals.

Apparent total-tract digestibility of nutrients was determined by total collection of the feces and urine from 31 to $33 \mathrm{~d}$ ( 29 to $27 \mathrm{~d}$ before the expected calving date) of the experiment (no outdoor exercise during total collection period). Feces and urine were collected separately by fitting cows with indwelling bladder catheters (75-mL capacity balloon, Bardex Foley Catheter, C. R. Bard Inc., Covington, GA) as described by Walter et al. (2012). Briefly, indwelling bladder catheters were inserted into bladder to separate urine and feces; urine was collected into a $20-\mathrm{L}$ container via catheter, and feces were collected from the floor. Both feces and urine were collected and weighed daily on the sampling days. Thoroughly mixed urine samples were subsampled daily and mixed by cow after total collection. Approximately $40 \mathrm{~mL}$ of the subsampled urine was collected into a 50$\mathrm{mL}$ centrifuge tube with screw cap and stored at $-20^{\circ} \mathrm{C}$ until further analyses. About $2 \%$ of the feces were collected daily into an aluminum pan, mixed thoroughly by cow after total collection, oven-dried at $55^{\circ} \mathrm{C}$, and then ground through a 1-mm screen (standard model 4 Wiley mill; Arthur H. Thomas) for chemical analyses.

Maternal blood samples were collected once daily from a jugular vein before morning feeding at d 53 (7 $\mathrm{d}$ before the expected calving date; the actual calving date was $2.68 \pm 0.52 \mathrm{~d}$ before the expected calving date) of the experimental period. Calves were weighed immediately after birth, fed $2 \mathrm{~L}$ of colostrum within 2 $\mathrm{h}$, and bled at $24 \mathrm{~h}$ after birth. Vacuum tubes (Becton Dickinson, Franklin Lakes, NJ) with Na heparin or without any additive (cat. no. 367614) were used to collect plasma and serum, respectively. Both plasma and serum were stored at $-20^{\circ} \mathrm{C}$ for further analyses. Within $2 \mathrm{~h}$ after birth, approximately $120 \mathrm{~mL}$ of colostrum was divided into 3 portions, placed in $50-\mathrm{mL}$ screw-cap centrifuge tubes, and then stored at $-20^{\circ} \mathrm{C}$ for further analyses.

Ruminal fluid was collected before morning feeding at d 30 before the expected calving date by a trained person, using an oral stomach tube as described by Shen et al. (2012). Ruminal pH was measured immediately after collection, squeezed through 4 layers of cheesecloth, divided into 4 portions, and stored at $-20^{\circ} \mathrm{C}$ for further analyses. Two subsamples of $5 \mathrm{~mL}$ of ruminal fluid were mixed with $1 \mathrm{~mL}$ of $25 \%$ (wt/vol) $\mathrm{HPO}_{3}$ and $1 \mathrm{~mL}$ of $1 \%$ (wt/vol) $\mathrm{H}_{2} \mathrm{SO}_{4}$ for VFA and $\mathrm{NH}_{3}-\mathrm{N}$ determination, respectively (Shen et al., 2018). One subsample was stored at $-20^{\circ} \mathrm{C}$ directly for the analysis of ruminal $\mathrm{Zn}$. The remaining subsamples of $40 \mathrm{~mL}$ of ruminal fluid were placed into a 50-mL screw-cap centrifuge tube for the analysis of microbial CP (MCP).

\section{Sample Analyses}

The feed, refusals, and feces were analyzed for DM, ash, ether extract, and CP (methods 930.15, 942.05, 920.39, and 996.11, respectively) according to AOAC International (2005). The OM content was calculated as $\mathrm{OM}=100 \%-$ ash \%. The content of NDF was measured as described by Van Soest et al. (1991) using heat-stable $\alpha$-amylase and sodium sulfite, and ADF of feeds and feces was determined according to AOAC International (2005; method 973.18). Both NDF and ADF were expressed inclusive of residual ash (Mertens, 2002). Concentration of ruminal VFA was determined by GC (GC-14B, Shimadzu, Kyoto, Japan; $30 \mathrm{~m} \times 0.32$ $\mathrm{mm} \times 0.25 \mathrm{~mm}$; column temperature, $110^{\circ} \mathrm{C}$; injector temperature, $180^{\circ} \mathrm{C}$; and detector temperature, $180^{\circ} \mathrm{C}$ ) as described by Shen et al. (2019). Concentration of ruminal $\mathrm{NH}_{3}-\mathrm{N}$ was determined using the method of Rhine et al. (1998), and ruminal MCP content was determined as described by Cotta and Russell (1982), with differential centrifugation used to isolate MCP. Flame atomic absorption spectroscopy was used to determine the $\mathrm{Zn}$ of feed offered, refusals, feces, urine, colostrum, ruminal fluid, and the maternal and calf serum as described by Osorio et al. (2016).

Concentration of serum alkaline phosphatase (ALP), carboxypeptidase, $\mathrm{Cu}$ and $\mathrm{Zn}$ superoxide dismutase (Cu-Zn SOD), total antioxidant capacity (T-AOC), and IL-1, 2, 4, and 6 were measured using commercial ELISA kits (Biosino Biotechnology Co. Ltd., Beijing, China). Concentrations of plasma nonesterified fatty acid (NEFA) and BHB were determined using commercial colorimetry kits (Nanjing Jiancheng Bioengineering Inc., Nanjing, China). Colostrum composition, including lactose, fat, protein, total solids, and nonfat 
Table 2. Effects of Zn supplementation on prepartum DMI and feed digestibility in dairy cows

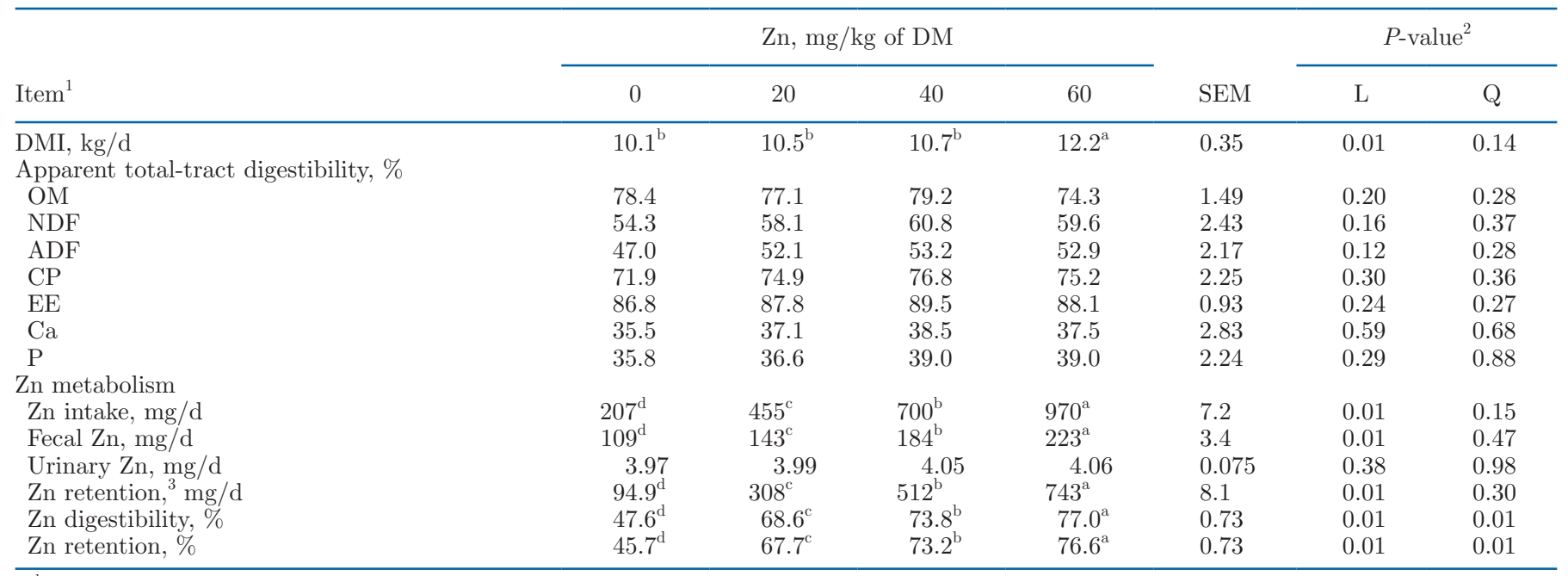

\footnotetext{
${ }^{\mathrm{a}-\mathrm{d}}$ Different superscripts within a row represent significant differences $(P<0.05)$.

${ }^{1}$ Apparent total-tract digestibility was measured during 27 to $29 \mathrm{~d}$ before the expected calving date; $\mathrm{EE}=$ ether extract.

${ }^{2} \mathrm{~L}$ and $\mathrm{Q}=$ linear and quadratic effects of $\mathrm{Zn}$ supplementation dose $(0,20,40,60 \mathrm{mg} / \mathrm{kg}$ of DM).

${ }^{3} \mathrm{Zn}$ retention $=\mathrm{Zn}$ intake - fecal $\mathrm{Zn}-$ urinary $\mathrm{Zn}$.
}

solids, was determined using a MilkoScan FT 120 (Foss Electric, Hillerød, Denmark). Commercial ELISA kits [MBS702497 (detection range: 1.56-100 $\mu \mathrm{g} / \mathrm{mL}$ ), MBS282896 (detection range: $0.16-10.00 \mu \mathrm{g} / \mathrm{mL}$ ), and MBS285353 (detection range: 31.25-2,000 $\mu \mathrm{g} / \mathrm{mL}$ ), respectively; MyBioSource Inc., San Diego, CA] were used to determine $\operatorname{Ig} \mathrm{A}, \operatorname{IgM}$, and $\operatorname{IgG}$ concentrations of colostrum and calf serum IgA, IgM, and IgG, respectively, as described by Ding et al. (2019). The interassay coefficients of variation were lower than $10 \%$, and the intraassay coefficients of variation were lower than $12 \%$.

\section{Calculations and Statistical Analyses}

Apparent digestibility of nutrients was calculated as described by Beckman and Weiss (2005) using the following equation: nutrient digestibility $=100 \%-[$ feces weight, $\mathrm{kg}) \times($ fecal nutrient content, \%)/(DMI, $\mathrm{kg})$ $\times$ (feed nutrient content, \%)]\%. Data were analyzed using PROC MIXED of SAS (SAS Inst. Inc., Cary, NC) for a randomized complete design. Treatment was the fixed effect, and the cow was the random effect in the MIXED model. The PDIFF option adjusted by the Tukey method was included in the LSMEANS statement to account for multiple comparisons among treatments when the $F$ test was significant. Specific preplanned contrasts were used to determine the linear and quadratic responses to increasing Zn-Met dose. Treatment effects were declared significant at $P \leq 0.05$, and trends were discussed at $0.05<P<0.10$ unless otherwise stated.

\section{RESULTS}

Apparent total-tract digestibility of $\mathrm{OM}, \mathrm{CP}, \mathrm{NDF}$, $\mathrm{ADF}$, ether extract, $\mathrm{Ca}$, and $\mathrm{P}$ were not affected, whereas DMI increased linearly $(P<0.05)$ with increasing amounts of Zn-Met (Table 2). The magnitude of DMI increase was more pronounced with $60 \mathrm{mg} / \mathrm{kg}$ of DM $(+21 \%)$ than with $20(+4 \%)$ and $40 \mathrm{mg} / \mathrm{kg}$ of DM $(+5.9 \%)$ compared with the control. The Zn intake and fecal Zn linearly $(P<0.01)$ increased with increasing Zn-Met supplementation dosage. Fecal Zn discharge increased linearly $(P<0.01)$ as well. However, urinary Zn excretion was not affected by Zn-Met supplementation. Total-tract digestibility of Zn linearly increased $(P$ $<0.01)$ with increasing amounts of Zn-Met. Likewise, the amount of $\mathrm{Zn}$ deposited in dairy cows increased linearly by $48.1,60.2$, and $67.6 \%$ with 20,40 , and 60 $\mathrm{mg}$ of $\mathrm{Zn} / \mathrm{kg}$ of $\mathrm{DM}$, respectively.

No treatment effect was observed in the concentration of ruminal Zn (Table 3). With increasing Zn-Met supplementation, ruminal concentration of ammonia decreased $(P<0.01)$, whereas the concentration of MCP increased $(P<0.01)$ linearly. Ruminal $\mathrm{pH}$ did not differ among treatments, whereas the concentration of total VFA increased linearly $(P<0.01)$ with increasing Zn-Met supplementation. No treatment effect was observed on molar proportion of ruminal acetate 
Table 3. Effects of Zn supplementation on rumen fermentation in prepartum dairy cows

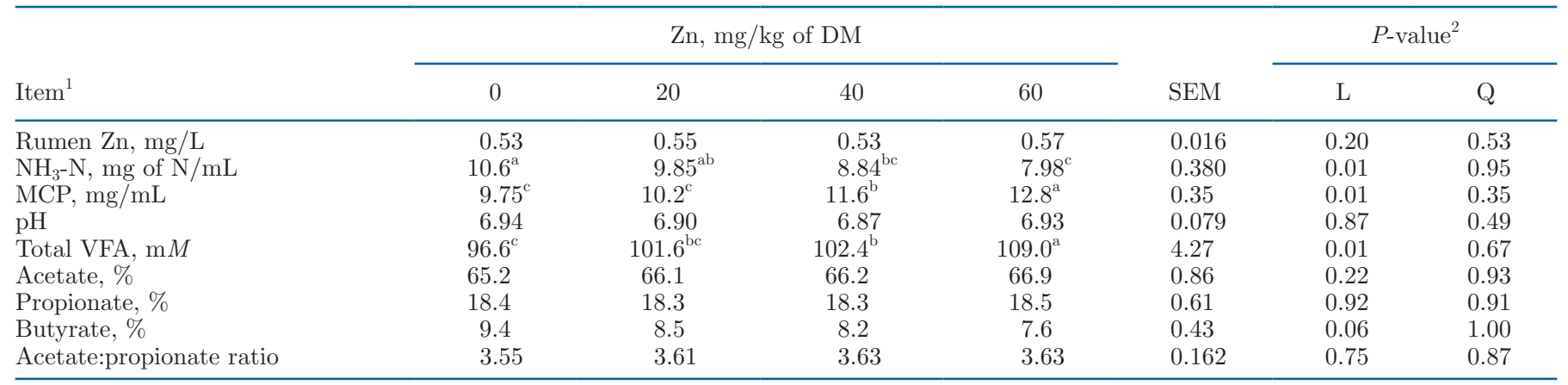

${ }^{\mathrm{a}-\mathrm{c}}$ Different superscripts within a row represent significant differences $(P<0.05)$.

${ }^{1} \mathrm{MCP}=$ microbial crude protein.

${ }^{2} \mathrm{~L}$ and $\mathrm{Q}=$ linear and quadratic effects of $\mathrm{Zn}$ supplementation dose $(0,20,40,60 \mathrm{mg} / \mathrm{kg}$ of DM).

or propionate or acetate:propionate ratio. The molar proportion of butyrate tended $(P<0.06)$ to decrease linearly with increasing Zn-Met supplementation.

With increasing supplementation of Zn-Met, the concentrations of ALP, carboxypeptidase, Cu-Zn SOD, and T-AOC increased linearly $(P<0.01)$ in maternal blood (Table 4). Maternal blood concentration of IL-1 decreased $(P<0.05)$, whereas IL-2 increased $(P<$ $0.05)$ and IL-6 tended $(P=0.06)$ to increase linearly with increasing Zn-Met supplementation. However, adding Zn-Met in the diet of dry cows had no effect on maternal blood concentration of IL-4, NEFA, or BHB.

Colostrum composition is shown in Table 5. No treatment effect was observed in colostrum composition except a trend $(P=0.10)$ toward increased lactose concentration. With increasing Zn supplementation, colostrum lactose percentage increased by 11.6, 6.8, and $44.2 \%$, respectively.

Blood concentrations of $\mathrm{Zn}$ and immunoglobulins (including $\operatorname{Ig} \mathrm{A}, \operatorname{Ig} \mathrm{G}$, and $\operatorname{IgM}$ ) of the dam were not affected by Zn-Met supplementation (Table 6). Colostrum concentration of $\mathrm{Zn}, \operatorname{IgA}$, and IgM increased linearly $(P<0.05)$. However, though the calf serum concentration of Zn linearly $(P<0.05)$ increased with increasing amount of $\mathrm{Zn}$-Met, the immunoglobulin concentration did not differ among treatments. The percentage increase in colostrum $\mathrm{Zn}(17.6,29.7$, and $40.7 \%$ for the supplementation of Zn at 20, 40, and 60 $\mathrm{mg} / \mathrm{kg}$ of DM, respectively) and calf blood $(0.5,22.7$, and $40.1 \%$ for the supplementation of $\mathrm{Zn}$ at 20,40 , and $60 \mathrm{mg} / \mathrm{kg}$ of DM, respectively) was similar except for the dose of $20 \mathrm{mg} / \mathrm{kg}$ of DM.

\section{DISCUSSION}

In the present study, $\mathrm{Zn}$ was added into the diet of dry cows in the form of Zn-Met at the doses of 0, 20, 40, and $60 \mathrm{mg}$ of $\mathrm{Zn} / \mathrm{kg}$ of DM. As an organic $\mathrm{Zn}$ source, feeding Zn-Met to dairy cows showed improvement of productive performance and health status in lactat-

Table 4. Effects of Zn supplementation on blood indicators in prepartum dairy cows

\begin{tabular}{|c|c|c|c|c|c|c|c|}
\hline Item $^{1}$ & \multicolumn{4}{|c|}{$\mathrm{Zn}, \mathrm{mg} / \mathrm{kg}$ of $\mathrm{DM}$} & SEM & \multicolumn{2}{|c|}{$P$-value ${ }^{2}$} \\
\hline$\overline{\mathrm{ALP}}, \mathrm{U} / \mathrm{L}$ & $83.6^{\mathrm{b}}$ & $87.1^{\mathrm{b}}$ & $92.8^{\mathrm{a}}$ & $91.9^{\mathrm{a}}$ & 1.25 & 0.01 & 0.11 \\
\hline $\mathrm{Cu}-\mathrm{Zn}$ SOD, ng/mL & $107^{\mathrm{b}}$ & $121^{\mathrm{a}}$ & $133^{\mathrm{a}}$ & $130^{\mathrm{a}}$ & 4.5 & 0.01 & 0.09 \\
\hline $\mathrm{T}-\mathrm{AOC}, \mathrm{U} / \mathrm{mL}$ & $8.8^{\mathrm{b}}$ & $9.7^{\mathrm{ab}}$ & $11.4^{\mathrm{a}}$ & $10.8^{\mathrm{a}}$ & 0.59 & 0.01 & 0.22 \\
\hline IL-1, ng/L & 140 & 133 & 117 & 108 & 9.6 & 0.02 & 0.92 \\
\hline IL-6, ng/L & 51.2 & 52.5 & 60.7 & 71.5 & 7.48 & 0.06 & 0.54 \\
\hline NEFA, mmol/L & 323 & 310 & 303 & 301 & 9.6 & 0.12 & 0.55 \\
\hline $\mathrm{BHB}, \mu \mathrm{mol} / \mathrm{L}$ & 7.01 & 6.61 & 6.80 & 7.08 & 0.46 & 0.86 & 0.48 \\
\hline
\end{tabular}

${ }^{\mathrm{a}, \mathrm{b}}$ Different superscripts within a row represent significant differences $(P<0.05)$.

${ }^{1} \mathrm{ALP}=$ alkaline phosphatase $\mathrm{Cu}-\mathrm{Zn} \mathrm{SOD}=\mathrm{Cn}$ and $\mathrm{Zn}$ superoxide dismutase; $\mathrm{T}-\mathrm{AOC}=$ total antioxidant capacity; NEFA $=$ nonesterified fatty acid.

${ }^{2} \mathrm{~L}$ and $\mathrm{Q}=$ linear and quadratic effects of $\mathrm{Zn}$ supplementation dose $(0,20,40,60 \mathrm{mg} / \mathrm{kg}$ of DM). 
Table 5. Effects of Zn supplementation on the composition of colostrum in dairy cows

\begin{tabular}{|c|c|c|c|c|c|c|c|}
\hline \multirow[b]{2}{*}{ Item } & \multicolumn{4}{|c|}{$\mathrm{Zn}, \mathrm{mg} / \mathrm{kg}$ of DM } & \multirow[b]{2}{*}{ SEM } & \multicolumn{2}{|c|}{$P$-value ${ }^{1}$} \\
\hline & 0 & 20 & 40 & 60 & & $\mathrm{~L}$ & $\mathrm{Q}$ \\
\hline Fat, $\%$ & 5.64 & 6.75 & 6.78 & 5.80 & 0.599 & 0.86 & 0.12 \\
\hline Protein, \% & 18.1 & 17.4 & 19.4 & 13.6 & 1.95 & 0.21 & 0.22 \\
\hline Lactose, \% & 1.90 & 2.12 & 2.03 & 2.74 & 0.294 & 0.10 & 0.42 \\
\hline SNF, $\%$ & 20.3 & 21.0 & 19.9 & 18.0 & 1.68 & 0.32 & 0.46 \\
\hline TS, $\%$ & 25.9 & 28.7 & 28.3 & 23.0 & 2.74 & 0.47 & 0.17 \\
\hline
\end{tabular}

${ }^{1} \mathrm{~L}$ and $\mathrm{Q}=$ linear and quadratic effects of Zn supplementation dose $(0,20,40,60 \mathrm{mg} / \mathrm{kg}$ of DM).

ing cows by increasing milk yield and decreasing SCC (Kellogg et al., 2004). However, the effect of Zn-Met in periparturient cows has been scarcely evaluated.

Cows supplemented with $\mathrm{Zn}$ at $60 \mathrm{mg} / \mathrm{kg}$ of DM increased DMI in the present study. Previous studies in either heifers or lactating cows showed that Zn supplementation from 5 to $65 \mathrm{mg} / \mathrm{kg}$ of DM had no effect on DMI (Arelovich et al., 2000; Cope et al., 2009). In contrast, a reduction in DMI with Zn supplementation was reported in steers (Malcolm-Callis et al., 2000) and in dairy goats (Salama et al., 2003). A study using a sheep model found that by increasing the Zn-Met in diet from 0 to $0.4,0.8$, and $1.2 \mathrm{~g} / \mathrm{d}$ (equal to $0,48,98$, and $136 \mathrm{mg}$ of $\mathrm{Zn} / \mathrm{kg}$ of DM), DMI linearly increased from 770 to 826,816 , and $881 \mathrm{~g} / \mathrm{d}$ (Jafarpour et al., 2015). Nayeri et al. (2014) suggested that the observed differences in DMI among studies may be due to the breed, production stage, level and source of $\mathrm{Zn}$, and treatment duration. Chen et al. (2000) and Mantzoros et al. (1998) found that Zn supplementation can enhance the leptin level in humans by increasing the IL-2 level. Leptin is associated with appetite and plays an important role in regulating DMI in dairy cows (Liefers et al., 2003). In the present study, though the concentration of leptin was not measured, the increased DMI may be the result of $\mathrm{Zn}$ increasing IL-2, which in turn increases leptin.

Zinc is an essential component in digestive enzymes; hence, its dietary supplementation might improve activities of digestive enzymes in the gut. In pigs, Hu et al. (2012) found that Zn supplementation at a dose of $62.5 \mathrm{mg} / \mathrm{kg}$ of DM improved the activities of protease, amylase, lipase, trypsin, and chymotrypsin. Using an in vitro study, Martinez and Church (1970) found that at low doses $(5 \mathrm{mg} / \mathrm{L})$, Zn increased cellulose digestibility, whereas at high doses, it decreased cellulose digestibility $(20 \mathrm{mg} / \mathrm{L})$. Moreover, Zn-Met was also reported to have a negative effect on nutrient digestibility compared with inorganic Zn (Caldera et al., 2019). Thus, it was expected that Zn-Met supplementation would have a negative effect on nutrient digestibility. However, in the present study, supplementing 0 to $60 \mathrm{mg}$ of $\mathrm{Zn} / \mathrm{kg}$ of DM had no effect on ruminal Zn concentration, which may explain the lack of an effect of $\mathrm{Zn}$ supplementation

Table 6. Effects of Zn supplementation on the concentration of $\mathrm{Zn}$ and immunoglobulins in maternal blood, colostrum, and calf blood

\begin{tabular}{|c|c|c|c|c|c|c|c|}
\hline \multirow[b]{2}{*}{ Item } & \multicolumn{4}{|c|}{$\mathrm{Zn}, \mathrm{mg} / \mathrm{kg}$ of $\mathrm{DM}$} & \multirow[b]{2}{*}{ SEM } & \multicolumn{2}{|c|}{$P$-value ${ }^{1}$} \\
\hline & 0 & 20 & 40 & 60 & & $\mathrm{~L}$ & $\mathrm{Q}$ \\
\hline \multicolumn{8}{|l|}{ Maternal blood } \\
\hline $\mathrm{Zn}, \mu \mathrm{mol} / \mathrm{L}$ & 10.3 & 11.9 & 12.1 & 12.0 & 0.72 & 0.14 & 0.30 \\
\hline $\mathrm{IgA}, \mu \mathrm{g} / \mathrm{mL}$ & 2.54 & 2.94 & 2.95 & 2.98 & 0.261 & 0.27 & 0.49 \\
\hline $\mathrm{IgG}, \mu \mathrm{g} / \mathrm{mL}$ & 21.8 & 23.3 & 21.5 & 24.9 & 2.30 & 0.47 & 0.68 \\
\hline $\mathrm{IgM}, \mu \mathrm{g} / \mathrm{mL}$ & 4.77 & 5.50 & 5.48 & 5.43 & 0.550 & 0.45 & 0.49 \\
\hline \multicolumn{8}{|l|}{ Colostrum } \\
\hline $\mathrm{Zn}, \mathrm{mg} / \mathrm{L}$ & $6.04^{\mathrm{b}}$ & $6.07^{\mathrm{b}}$ & $7.41^{\mathrm{a}}$ & $8.46^{\mathrm{a}}$ & 0.404 & 0.01 & 0.23 \\
\hline $\mathrm{IgA}, \mathrm{mg} / \mathrm{mL}$ & 12.0 & 13.8 & 17.3 & 17.3 & 2.03 & 0.06 & 0.67 \\
\hline $\mathrm{IgG}, \mathrm{mg} / \mathrm{mL}$ & $76.7^{\mathrm{b}}$ & $79.7^{\mathrm{b}}$ & $90.5^{\mathrm{a}}$ & $89.8^{\mathrm{a}}$ & 3.09 & 0.01 & 0.57 \\
\hline $\mathrm{IgM}, \mathrm{mg} / \mathrm{mL}$ & 21.4 & 23.0 & 28.0 & 27.9 & 4.50 & 0.26 & 0.86 \\
\hline \multicolumn{8}{|l|}{ Calf blood } \\
\hline $\mathrm{Zn}, \mu \mathrm{mol} / \mathrm{L}$ & $9.1^{\mathrm{d}}$ & $10.7^{\mathrm{c}}$ & $11.8^{\mathrm{b}}$ & $12.8^{\mathrm{a}}$ & 0.32 & 0.01 & 0.39 \\
\hline $\mathrm{IgA}, \mathrm{mg} / \mathrm{mL}$ & 2.24 & 2.27 & 2.36 & 2.36 & 0.176 & 0.57 & 0.94 \\
\hline $\mathrm{IgG}, \mathrm{mg} / \mathrm{mL}$ & 28.8 & 28.8 & 29.4 & 29.1 & 1.42 & 0.80 & 0.92 \\
\hline $\mathrm{IgM}, \mathrm{mg} / \mathrm{mL}$ & 4.17 & 4.13 & 4.19 & 4.15 & 0.226 & 0.98 & 1.00 \\
\hline
\end{tabular}

${ }^{\mathrm{a}-\mathrm{d}}$ Different superscripts within a row represent significant differences $(P<0.05)$.

${ }^{1} \mathrm{~L}$ and $\mathrm{Q}=$ linear and quadratic effects of $\mathrm{Zn}$ supplementation dose $(0,20,40,60 \mathrm{mg} / \mathrm{kg}$ of DM). 
on nutrient digestibility. Similarly, a lack of effect on DM digestibility has been reported in heifers by Arelovich et al. (2000), and Salama et al. (2003) reported greater digestibility of $\mathrm{DM}, \mathrm{OM}$, and $\mathrm{CP}$ in dairy goats supplemented with Zn.

In the present study, the linear increase in $\mathrm{Zn}$ digestibility with increasing Zn supplementation was expected because the organic form is more stable in the digestive tract and readily absorbable (Uchida et al., 2001). The digestibility of $\mathrm{Zn}$ ranged from 47.6 to $77 \%$ in this study, which agreed with a previous study (range from 45.4 to $76.1 \%$; Balabánová et al., 2014). Ziegler et al. (1989) reported that urinary Zn concentration was not affected by Zn supplementation, and Spears and Kegley (2002) found no significant difference in urinary Zn excretion when supplemented with either inorganic $(\mathrm{ZnO})$ or organic $\mathrm{Zn}$ (Zn-Met). Therefore, lack of differences in urinary $\mathrm{Zn}$ concentration among treatments was consistent with other studies.

An interesting finding in this study was that, though the $\mathrm{Zn}$ supplementation increased significantly, the ruminal soluble $\mathrm{Zn}$ did not differ among treatments. One possible explanation could be that most of the supplemented $\mathrm{Zn}$ was used by the ruminal bacteria. Eryavuz and Dehority (2009) reported greater increase in $\mathrm{Zn}$ concentration in both cellulolytic and total bacteria after $48 \mathrm{~h}$ of in vitro incubation in the supplemented group compared with the control (4.8 vs. $129.5 \times 10^{7} /$ $\mathrm{mL}$ for cellulolytic bacteria and 17.6 vs. $224.0 \times 10^{7} /$ $\mathrm{mL}$ for total bacteria). In the present study, though the amount of ruminal bacteria was not detected, the ruminal ammonia and MCP concentration decreased and increased linearly, respectively. Hence, lack of differences in ruminal $\mathrm{Zn}$ concentration among treatments may be explained by greater ruminal bacteria in cows supplemented with more Zn. Less ammonia and greater MCP concentration in sheep supplemented with ZnMet has also been reported by Ashry et al. (2012). Another possible explanation for the lack of difference in ruminal soluble $\mathrm{Zn}$ concentration among treatments could be the solubility of Zn-Met. The Zn-Met used in the present study was water soluble, and thus may have flowed with the fluid fraction of the rumen contents, resulting in a short residence time in the rumen. The rumen samples were collected before the morning feeding, which in theory should have been the longest period of time between meals and allowed the most time for nutrients associated with the fluid fraction to leave the rumen.

Ruminal pH and total VFA concentration are important indicators to evaluate rumen fermentation. Usually, the ruminal $\mathrm{pH}$ is negatively associated with DMI and total VFA concentration (Shen et al., 2018). In the present study, DMI and total VFA concentration were greater in cows supplemented with $60 \mathrm{mg}$ of $\mathrm{Zn} / \mathrm{kg}$ of DM compared with the other treatments, whereas ruminal $\mathrm{pH}$ did not differ among treatments. Both saliva contamination and sampling locations in the rumen could affect ruminal $\mathrm{pH}$. However, in this study, the rumen sampling was taken by the same person and followed the same procedure, thus minimizing the effect of nontreatment factors on results. The reason for similar ruminal $\mathrm{pH}$ was not clear. Ruminal $\mathrm{pH}$ is associated with total VFA concentration and saliva excretion; hence, adding Zn-Met to dairy cows may have some potential effect on saliva excretion. Ishii et al. (1999) suggested that Zn, together with some Zn-dependent enzymes, plays an important role in saliva excretion. Even though our data cannot sufficiently support this hypothesis, we speculate that the lack of differences in ruminal $\mathrm{pH}$ together with greater total VFA concentration may be explained by greater saliva excretion in cows supplemented with Zn at $60 \mathrm{mg} / \mathrm{kg}$ of DM. Greater VFA concentration with no differences in ruminal pH in sheep supplemented with Zn-Met compared with $\mathrm{ZnSO}_{4}$ was also reported by Ashry et al. (2012).

Alkaline phosphatase and carboxypeptidase are Zndependent enzymes that can be used to evaluate $\mathrm{Zn}$ status in dairy cows (Arelovich et al., 2000; Yan et al., 2002). In the present study, activity of ALP and carboxypeptidase was greater in cows supplemented with 40 and $60 \mathrm{mg}$ of $\mathrm{Zn} / \mathrm{kg}$ of DM, suggesting that $40 \mathrm{mg}$ or more of Zn/kg of DM as Zn-Met may be beneficial in improving the activity of these Zn-dependent enzymes.

The concentration of $\mathrm{Cu}-\mathrm{Zn} \mathrm{SOD}$ and T-AOC activity are commonly used to evaluate the antioxidant status in animals (Zhang et al., 2013; Xu et al., 2014). The linear increase of $\mathrm{Cu}-\mathrm{Zn} \mathrm{SOD}$ and T-AOC concentration with an increase in the amount of Zn-Met in the present study suggested a greater antioxidant capacity in cows receiving greater amounts of Zn-Met. Previously, researchers reviewing the role of $\mathrm{Zn}$ in mice and monkeys reported its importance in improving the antioxidant capacity (Stefanidou et al., 2006). In the present study, the levels of $\mathrm{Cu}-\mathrm{Zn}$ SOD and T-AOC were similar and significantly greater in cows supplemented with Zn (as Zn-Met) at $\geq 40 \mathrm{mg} / \mathrm{kg}$ of DM than the control, suggesting that $40 \mathrm{mg} / \mathrm{kg}$ of DM should be high enough to provide greater antioxidant capacity.

Interleukins are cytokines secreted by different cells, including monocytes, lymphocytes, and macrophages, and play an important role in immune regulation. Interleukin-1, IL-2, and IL-6 can promote the growth and differentiation of $\mathrm{B}$ cells and the secretion of antibodies, improving immune competence. However, some researchers believe that these cytokines also indicate body infection. In the present study, no infection was observed during the experiment. Although the mater- 
nal blood concentration of immunoglobulins was not affected, the greater IgA and IgG concentrations in colostrum also illustrated an improved immune status in Zn-Met-supplemented cows. Thus, the linearly increased blood concentration of IL-2 and IL-6 with increasing Zn-Met supplementation reflected an improved immune status of dairy cows. This agreed with a previous review (Stefanidou et al., 2006). Both NEFA and $\mathrm{BHB}$ are important in evaluating the lipid metabolism in ruminants. In the present study, the lack of differences in maternal serum concentrations of NEFA and BHB among treatments illustrated that Zn supplementation may have no effect on lipid metabolism. Similarly, Zn supplementation did not affect NEFA and BHB in previous research (Nayeri et al., 2014).

Zinc concentration in colostrum did not vary between cows supplemented with Zn at different levels (Cope et al., 2009), which is inconsistent with our results. In the present study, though the Zn concentration in maternal blood did not differ, the concentration in colostrum increased linearly with increasing in Zn-Met supplementation. Serum Zn represents only $0.1 \%$ of wholebody Zn; its concentration is regulated by homeostatic mechanisms and maintains balance even over a 10-fold Zn intake change (Roohani et al., 2013). Thus, serum Zn concentration could be used to reflect Zn deficiency but is not sensitive enough to reflect the increasing of Zn supplementation in healthy animals. In the present study, Zn concentration was not affected in maternal serum, even though we expected a linear increae in colostrum with increasing Zn-Met supplementation. The greater Zn concentration in colostrum of cows supplemented with Zn-Met was consistent with greater Zn transfer from blood to colostrum in our study. Wright and Spears (2004) found that blood Zn concentration increased in calves with diets supplemented with greater amounts of $\mathrm{Zn}$. The linear increase in blood Zn concentrations in calves was consistent with previous studies, though $\mathrm{Zn}$ was supplemented via diet in the previous study (Wright and Spears, 2004) and via colostrum in the present study.

Colostrum is important in passive immunity transfer, and early feeding of colostrum provides immunoglobulins to calves, which improves their immunity (Quigley and Drewry, 1998). Interestingly, the concentration of immunoglobulins did not differ in maternal blood, although it linearly increased in colostrum (except for IgG) with increasing Zn-Met supplementation. Similar results were also observed in cows supplemented with mannan oligosaccharides. Greater immunoglobulin concentrations were detected in colostrum, but not in maternal or calf blood (Franklin et al., 2005). In a review, Stefanidou et al. (2006) reported that Zn can improve the immune response by stimulating activity of immune cells. Thus, we expected the immunoglobulin concentration to be greater in both colostrum and maternal blood with Zn-Met supplementation. However, Blecha et al. (1981) showed that even under a CP restriction of more than $50 \%$, maternal serum concentration of immunoglobulins did not differ, which suggested that there may be potential pathways that ensure the immunoglobulin concentration remains stable.

It is well established that passive transfer of immunity in calves is mainly through colostrum feeding instead of through placental transfer (Hough et al., 1990); hence, we were confounded by the inconsistent tendency of $\operatorname{Ig} \mathrm{A}, \operatorname{IgM}$, and $\operatorname{IgG}$ concentrations between colostrum and calf blood in the present study. In another review, Weaver et al. (2000) reported that the passive immunity transfer could be affected by many factors such as timing of colostrum ingestion, the method and volume of colostrum administration, the immunoglobulin concentration of colostrum ingested, and the age of the dam. In our study, we fed $2 \mathrm{~L}$ of colostrum within 2 $\mathrm{h}$ after birth, followed by blood sampling after $24 \mathrm{~h}$, whereas previous studies that reported differences in immunoglobulins fed $1 \mathrm{~L}$ of colostrum every 8 or $12 \mathrm{~h}$ (Blecha et al., 1981; Hough et al., 1990). The lack of differences in calf immunoglobulin concentrations could be explained by either the lower volume of colostrum fed or the longer interval between feeding and blood sampling. Notwithstanding the aforementioned observations, the greater colostrum IgA and IgM concentrations of cows supplemented with Zn-Met suggested a potential benefit in passive immunity transfer. Because Zn supplemented as Zn-Met at 40 and $60 \mathrm{mg} / \mathrm{kg}$ of DM had no difference in colostrum IgA and IgM, but were both significantly greater than the control, supplementation of $40 \mathrm{mg}$ of $\mathrm{Zn} / \mathrm{kg} \mathrm{DM}$ should be adequate for passive immunity transfer.

\section{CONCLUSIONS}

Though nutrient digestibility was not affected, the results of this study demonstrated improved DMI and antioxidant capacity with Zn-Met supplementation. With increasing Zn-Met supplementation, colostrum concentration of IgA and IgM increased linearly, which suggested potential benefits in passive immunity transfer. However, similar observations were not found for the concentration of IgA and IgM in calf blood, which may be due to the low volume of colostrum fed, as well as the long interval between colostrum feeding and blood sampling. Based on the present results, supplementing prepartum cows with $40 \mathrm{mg}$ of Zn-Met/kg of DM will potentially improve the passive transfer of immunity. Further studies on the effect of Zn-Met supplementation on passive immunity transfer are desirable. 


\section{ACKNOWLEDGMENTS}

This research was financially supported by China Agriculture Research System (CARS-36, Beijing, China), Hebei Dairy Cattle Innovation Team of Modern Agro-industry Technology Research System (HBCT2018120203, Shijiazhuang, China), and key research and development project of Hebei (19226625D, Shijiazhuang, China). The authors thank the entire stuff of Jiulonghe Dairy Farm for their assistance in animal care and sample collection. The authors declare that the research was performed without any commercial or financial relationships that could be construed as potential conflicts of interest.

\section{REFERENCES}

AOAC International. 2005. Official Methods of Analysis. 18th ed. AOAC International, Washington, DC.

Arelovich, H. M., F. Owens, G. Horn, and J. Vizcarra. 2000. Effects of supplemental zinc and manganese on ruminal fermentation, forage intake, and digestion by cattle fed prairie hay and urea. J. Anim. Sci. 78:2972-2979. https://doi.org/10.2527/2000.78112972x.

Ashry, G. M. E., A. A. M. Hassan, and S. M. Soliman . 2012. Effect of feeding a combination of zinc, manganese and copper methionine chelates of early lactation high producing dairy cow. Food Nutr. Sci. 3:1084-1091. https://doi.org/10.4236/fns.2012.38144.

Balabánová, M., H. Śárka, and Z. Ladislav. 2014. The effect of inorganic and organic form of zinc on digestibility of nutrients in dairy cows in three stages of reproductive cycle. Acta Univ. Agric. Silvic. $59: 17-24$

Beckman, J. L., and W. P. Weiss. 2005. Nutrient digestibility of diets with different fiber to starch ratios when fed to lactating dairy cows. J. Dairy Sci. 88:1015-1023. https://doi.org/10.3168/jds .S0022-0302(05)72769-7.

Blecha, F., R. C. Bull, D. P. Olson, R. H. Ross, and S. Curtis. 1981. Effects of prepartum protein restriction in the beef cow on immunoglobin content in blood and colostral whey and subsequent immunoglobin absorption by the neonatal calf. J. Anim. Sci. 53:1174-1180. https://doi.org/10.2527/jas1981.5351174x.

Caldera, E., B. Weigel, V. N. Kucharczyk, K. S. Sellins, S. L. Archibeque, J. J. Wagner, H. Han, J. W. Spears, and T. E. Engle. 2019. Trace mineral source influences ruminal distribution of copper and zinc and their binding strength to ruminal digesta. J. Anim. Sci. 97:1852-1864. https://doi.org/10.1093/jas/skz072.

Chen, M. D., Y. M. Song, and P. Y. Lin. 2000. Zinc may be a mediator of leptin production in humans. Life Sci. 66:2143-2149. https://doi .org/10.1016/S0024-3205(00)00541-5.

Cope, C. M., A. M. Mackenzie, D. Wilde, and L. A. Sinclair. 2009. Effects of level and form of dietary zinc on dairy cow performance and health. J. Dairy Sci. 92:2128-2135. https://doi.org/10.3168/ jds.2008-1232.

Cotta, M. A., and J. B. Russell. 1982. Effect of peptides and amino acids on efficiency of rumen bacterial protein synthesis in continuous culture. J. Dairy Sci. 65:226-234. https://doi.org/10.3168/jds .S0022-0302(82)82181-4.

Ding, L. Y., Y. F. Wang, Y. Z. Shen, G. Zhou, X. Zhang, M. Z. Wang, J. J. Loor, and J. Zhang. 2019. Effects of arginase inhibition via jugular infusion of Nw-hydroxy-nor-l-arginine on metabolic and immune indices in lactating dairy cows. J. Dairy Sci. 102:33103320. https://doi.org/10.3168/jds.2018-14879.

Eryavuz, A., and B. A. Dehority. 2009. Effects of supplemental zinc concentration on cellulose digestion and cellulolytic and total bacterial numbers in vitro. Anim. Feed Sci. Technol. 151:175-183. https://doi.org/10.1016/j.anifeedsci.2009.01.008.
Franklin, S. T., M. C. Newman, K. E. Newman, and K. I. Meek. 2005. Immune parameters of dry cows fed mannan oligosaccharide and subsequent transfer of immunity to calves. J. Dairy Sci. 88:766775. https://doi.org/10.3168/jds.S0022-0302(05)72740-5.

Garg, A. K., V. Mudgal, and R. S. Dass. 2008. Effect of organic zinc supplementation on growth, nutrient utilization and mineral profile in lambs. Anim. Feed Sci. Technol. 144:82-96. https://doi.org/ 10.1016/j.anifeedsci.2007.10.003.

Hough, R. L., F. McCarthy, H. Kent, D. Eversole, and M. Wahlberg. 1990. Influence of nutritional restriction during late gestation on production measures and passive immunity in beef cattle. J. Anim. Sci. 68:2622-2627. https://doi.org/10.2527/1990.6892622x.

Hu, C., J. Song, Z. You, Z. Luan, and W. Li. 2012. Zinc oxide-montmorillonite hybrid influences diarrhea, intestinal mucosal integrity, and digestive enzyme activity in weaned pigs. Biol. Trace Elem. Res. 149:190-196. https://doi.org/10.1007/s12011-012-9422-9.

Ishii, K., M. Akita, M. Sato, and H. Tomita. 1999. Localization of zinc in the rat submandibular gland and the effect of its deficiency on salivary secretion. Ann. Otol. Rhinol. Laryngol. 108:300-308. https://doi.org/10.1177/000348949910800315.

Jafarpour, N., M. Khorvash, H. Rahmani, A. Pezeshki, and M. Hosseini Ghaffari. 2015. Dose-responses of zinc-methionine supplements on growth, blood metabolites and gastrointestinal development in sheep. J. Anim. Physiol. Anim. Nutr. (Berl.) 99:668-675. https:// doi.org/10.1111/jpn.12286.

Kellogg, D. W., M. T. Socha, D. J. Tomlinson, and A. B. Johnson. 2003. Effects of feeding cobalt glucoheptonate and metal specific amino acid complexes of zinc, manganese, and copper on lactation and reproductive performance of dairy cows. Prof. Anim. Sci. 19:1-9. https://doi.org/10.15232/S1080-7446(15)31367-X.

Kellogg, D. W., D. J. Tomlinson, M. T. Socha, and A. B. Johnson. 2004. Effects of zinc methionine complex on milk production and somatic cell count of dairy cows: Twelve-trial summary. Prof. Anim. Sci. 20:295-301. https://doi.org/10.15232/S1080-7446(15)31318-8.

Liefers, S. C., R. F. Veerkamp, M. F. W. Te Pas, C. Delavaud, Y. Chilliard, and T. Van der Lende. 2003. Leptin concentrations in relation to energy balance, milk yield, intake, live weight, and estrus in dairy cows. J. Dairy Sci. 86:799-807. https://doi.org/10.3168/ jds.S0022-0302(03)73662-5.

Malcolm-Callis, K. J., G. C. Duff, S. A. Gunter, E. B. Kegley, and D. A. Vermeire. 2000. Effects of supplemental zinc concentration and source on performance, carcass characteristics, and serum values in finishing beef steers. J. Anim. Sci. 78:2801-2808. https://doi .org/10.2527/2000.78112801x.

Mantzoros, C. S., A. S. Prasad, F. W. Beck, S. Grabowski, J. Kaplan, C. Adair, and G. J. Brewer. 1998. Zinc may regulate serum leptin concentrations in humans. J. Am. Coll. Nutr. 17:270-275. https:/ /doi.org/10.1080/07315724.1998.10718758.

Martinez, A., and D. Church. 1970. Effect of various mineral elements on in vitro rumen cellulose digestion. J. Anim. Sci. 31:982-990. https://doi.org/10.2527/jas1970.315982x.

Mertens, D. R. 2002. Gravimetric determination of amylase-treated neutral detergent fiber in feeds with refluxing in beakers or crucibles: Collaborative study. J. AOAC Int. 85:1217-1240.

Nayeri, A., N. C. Upah, E. Sucu, M. V. Sanz-Fernandez, J. M. DeFrain, P. J. Gorden, and L. H. Baumgard. 2014. Effect of the ratio of zinc amino acid complex to zinc sulfate on the performance of Holstein cows. J. Dairy Sci. 97:4392-4404. https://doi.org/10 $.3168 /$ jds.2013-7541.

NRC. 2001. Nutrient Requirements of Dairy Cattle, 7th ed. Natl. Acad. Press, Washington, DC.

Osorio, J. S., E. Trevisi, C. Li, J. K. Drackley, M. T. Socha, and J. J. Loor. 2016. Supplementing $\mathrm{Zn}, \mathrm{Mn}$, and $\mathrm{Cu}$ from amino acid complexes and Co from cobalt glucoheptonate during the peripartal period benefits postpartal cow performance and blood neutrophil function. J. Dairy Sci. 99:1868-1883. https://doi.org/10.3168/jds 2015-10040.

Pfeiffer, N. E., T. C. McGuire, R. B. Bendel, and J. M. Weikel. 1977. Quantitation of bovine immunoglobulins: Comparison of single radial immunodiffusion, zinc sulfate turbidity, serum electrophoresis, and refractometer methods. Am. J. Vet. Res. 38:693-698. 
Quigley, J. D. III., and J. J. Drewry . 1998. Nutrient and immunity transfer from cow to calf pre- and postcalving. J. Dairy Sci. 81:2779-2790. https://doi.org/10.3168/jds.S0022-0302(98)75836 $-9$.

Rhine, E. D., R. L. Mulvaney, E. J. Pratt, and G. K. Sims. 1998. Improving the Berthelot reaction for determining ammonium in soil extracts and water. Soil Sci. Soc. Am. J. 62:473-480. https://doi .org/10.2136/sssaj1998.03615995006200020026x.

Roohani, N., R. Hurrell, R. Kelishadi, and R. Schulin. 2013. Zinc and its importance for human health: An integrative review. J. Res. Med. Sci. 18:144-157.

Salama, A. A. K., G. Caja, E. Albanell, X. Such, R. Casals, and J. Plaixats. 2003. Effects of dietary supplements of zinc-methionine on milk production, udder health and zinc metabolism in dairy goats. J. Dairy Res. 70:9-17. https://doi.org/10.1017/ S0022029902005708.

Shen, J. S., Z. Chai, L. J. Song, J. X. Liu, and Y. M. Wu. 2012. Insertion depth of oral stomach tubes may affect the fermentation parameters of ruminal fluid collected in dairy cows. J. Dairy Sci. 95:5978-5984. https://doi.org/10.3168/jds.2012-5499.

Shen, Y. Z., L. Y. Ding, L. M. Chen, J. H. Xu, R. Zhao, W. Z. Yang, H. R. Wang, and M. Z. Wang. 2019. Feeding corn grain steeped in citric acid modulates rumen fermentation and inflammatory responses in dairy goats. Animal 13:301-308. https://doi.org/10 $.1017 /$ S1751731118001064.

Shen, Y., H. R. Wang, T. Ran, I. Yoon, A. M. Saleem, and W. Z. Yang. 2018. Influence of yeast culture and feed antibiotics on ruminal fermentation and site and extent of digestion in beef heifers fed high grain rations. J. Anim. Sci. 96:3916-3927. https://doi.org/10 .1093/jas/sky249.

Sobhanirad, S., D. Carlson, and R. B. Kashani. 2010. Effect of zinc methionine or zinc sulfate supplementation on milk production and composition of milk in lactating dairy cows. Biol. Trace Elem. Res. 136:48-54. https://doi.org/10.1007/s12011-009-8526-3.

Spears, J. W., and E. B. Kegley. 2002. Effect of zinc source (zinc oxide vs zinc proteinate) and level on performance, carcass characteristics, and immune response of growing and finishing steers. J. Anim. Sci. 80:2747-2752.

Stefanidou, M., C. Maravelias, A. Dona, and C. Spiliopoulou. 2006. Zinc: A multipurpose trace element. Arch. Toxicol. 80:1-9. https:/ /doi.org/10.1007/s00204-005-0009-5.

Uchida, K., P. Mandebvu, C. Ballard, C. Sniffen, and M. Carter. 2001. Effect of feeding a combination of zinc, manganese and copper amino acid complexes, and cobalt glucoheptonate on performance of early lactation high producing dairy cows. Anim. Feed Sci. Technol. 93:193-203. https://doi.org/10.1016/S0377-8401(01)00279-6.

Van Soest, P. J., J. B. Robertson, and B. A. Lewis. 1991. Methods for dietary fiber, neutral detergent fiber, and nonstarch polysaccharides in relation to animal nutrition. J. Dairy Sci. 74:3583-3597. https://doi.org/10.3168/jds.S0022-0302(91)78551-2.

Walter, L. J., T. A. McAllister, W. Z. Yang, K. A. Beauchemin, M. He, and J. J. McKinnon. 2012. Comparison of wheat or corn dried distillers grains with solubles on rumen fermentation and nutrient digestibility by feedlot heifers. J. Anim. Sci. 90:1291-1300. https:/ /doi.org/10.2527/jas.2011-3844.

Weaver, D. M., J. W. Tyler, D. C. VanMetre, D. E. Hostetler, and G. M. Barrington. 2000. Passive transfer of colostral immunoglobulins in calves. J. Vet. Intern. Med. 14:569-577. https://doi.org/10 $.1111 /$ j.1939-1676.2000.tb02278.x.

Wedekind, K. J., A. E. Hortin, and D. H. Baker. 1992. Methodology for assessing zinc bioavailability: Efficacy estimates for zinc-methionine, zinc sulfate, and zinc oxide. J. Anim. Sci. 70:178-187. https: //doi.org/10.2527/1992.701178x.

Weiss, W. P. 2017. A 100-year review: From ascorbic acid to zincMineral and vitamin nutrition of dairy cows. J. Dairy Sci. 100:10045-10060. https://doi.org/10.3168/jds.2017-12935.

Wright, C. L., and J. W. Spears. 2004. Effect of zinc source and dietary level on zinc metabolism in Holstein calves. J. Dairy Sci. 87:1085-1091. https://doi.org/10.3168/jds.S0022-0302(04)73254 $-3$.

Xu, J., C. Xu, X. Chen, X. Cai, S. Yang, Y. Sheng, and T. Wang. 2014 Regulation of an antioxidant blend on intestinal redox status and major microbiota in early weaned piglets. Nutrition 30:584-589. https://doi.org/10.1016/j.nut.2013.10.018.

Yan, J., Q. Cheng, C. B. Li, and S. Aksoy. 2002. Molecular characterization of three gut genes from Glossina morsitans morsitans: Cathepsin B, zinc-metalloprotease and zinc-carboxypeptidase. Insect Mol. Biol. 11:57-65. https://doi.org/10.1046/j.0962-1075.2001 .00308.x.

Zhang, L., C. Liu, D. Li, Y. Zhao, X. Zhang, X. Zeng, Z. Yang, and S. Li. 2013. Antioxidant activity of an exopolysaccharide isolated from Lactobacillus plantarum C88. Int. J. Biol. Macromol. 54:270275. https://doi.org/10.1016/j.ijbiomac.2012.12.037.

Ziegler, E. E., R. E. Serfass, S. E. Nelson, R. Figueroa-Colón, B. B. Edwards, R. S. Houk, and J. J. Thompson. 1989. Effect of low zinc intake on absorption and excretion of zinc by infants studied with 70Zn as extrinsic tag. J. Nutr. 119:1647-1653. https://doi.org/10 $.1093 /$ jn/119.11.1647. 